\title{
Human Capital Management as an Intensive Resource for the Development of Digital Economy
}

\author{
Kharchenko E.V.* \\ Southwest State University \\ Kursk, Russia \\ e-mail: swsu_buaia@mail.ru \\ Shleenko A.V. \\ Southwest State University \\ Kursk, Russia \\ e-mail: Shleenko77@mail.ru
}

\author{
Okunkova E.A. \\ Plekhanov Russian University of Economics \\ Moscow, Russia \\ e-mail: okunkova.ea@rea.ru \\ Alpeeva E.A. \\ NUST MISIS \\ Moscow, Russia \\ e-mail: alpeevael@yandex.ru
}

\begin{abstract}
The article presents the results of author's research on the genesis of a system-based paradigm of human capital of innovative economy, as a research concept that implements and specifies a holistic approach to identifying patterns and cause-effect relationships within the human capital system of innovative development. Special attention is paid to the influence of digital technologies on the processes of transformation of human capital management systems at macro and micro levels. The results of statistical analysis of the relationship between the intensity of costs for technological innovation and the combined level of innovative activity of organizations and the human development index at the international level are presented. The directions of using new technologies and innovative human capital management tools for the development of the digital economy are given, based on the analysis of the correlation between the level of formed human capital and the economic development of Russia for 1999-2016.
\end{abstract}

Keywords - human capital, human potential, innovative development, education.

\section{INTRODUCTION}

The evolution of human capital management concepts is changing in modern economic science. It is assigned a transformative role in the socio-cultural, economic and technological development of society. In this context human capital is an intensive resource for the development of digital economy. At the same time the question of the factors of human capital remains debatable taking into account its most important function. The classical concept of human capital is based on the triad: investment in education - development of human capital - economic growth, innovative transformations and social development. However, the current pace of digital technology development and its global spread is high. As a result, the institutions of socio-economic and technological progress cannot fully utilize their potential. The classical concept of human capital does not receive statistical confirmation in developed countries. Its transformation is taking place in relation to the innovative economy, where investment in innovation is the driving force of technological development, which requires the renewal of educational institutions and an increase in the quality of human resources training to ensure economic activity.

\section{METHODS AND MATERIALS}

To illustrate the formation of a new concept of human capital, we have used statistical data and the results of international studies in the field of human capital, innovative development and data from the Federal State Statistics Service of the Russian Federation, newsletters from the Higher School of Economics, Internet materials, open and closed sources, as well as authors' own research.

To solve the problems posed in the article we have used methods of empirical generalization, situational and system analysis, economic analysis and synthesis, monographic and genesis methods. The authors have used MS Excel spreadsheets to process and study the obtained data.

\section{RESULTS}

World-renowned scholars give the educational system a major role in the development of human capital as an intensive resource of the innovative economy (Figure 1). In 1992 Mankiw N.G, Romer D., Weil D. investigated the effect of education on labor productivity growth [1]. In 1998 Aghion R., and Howit P. established a connection between education and innovative potential [2]. The existence of a connection between the education of population and the investment attractiveness of the state was proved by Acemoglu, D., \& Angrist, J. in 2000 [3]. Benhabib J., Spiegel M. devoted their research to the impact of education on accelerating economic growth through the introduction of new technologies based on aggregated cross-country data [4].

Development basis of an innovative society, conditions for the development of national innovation systems in accordance with the classical concept of human capital are formed as a result of purposeful management of it. However, today the relationship between education and the innovative development of the economy is statistically confirmed only for developing countries, where there is an explicit relationship between the development of general education and economic growth.

The pace of technology development and its global spread is so high that institutions traditionally regarded as factors of socio-economic and technological progress (open labor market, state protectionism, protection of property rights, 
antitrust and foreign exchange policy, etc.) are not able to use their potential effectively. According to the assessment presented in the report "2017 Deloitte Global Human Capital Trends" [5], a person develops much more dynamic than organizations, institutions and states in accordance with technological changes. In the near future the main segment of the labor market and the generator of added value will be exclusively human interaction using modern digital technologies. Further economic growth, innovative development and digitalization are possible only through continuous improvement of institutions through proactive social action. This is absolutely not a revolutionary way. The evolution of the labor market and its institutions is taking place in this direction. The role of "common" human capital is increasing, and its value is superior to the value of "specific" and the importance of the " 21 st century" skills is growing [6].

Back in 2007 E. Hanushek, L. Wessman asked the question: how does the growth of human capital affect socioeconomic development? [7] It turns out that a statistically confirmed high growth of human capital is observed in countries where capital (technology, technology, innovation) and managerial competencies come in and stimulate the development of education to ensure economic activity, which contradicts the classical concept of human capital.

Thus, the leaders of the list of countries by the human development index [8], which have a very high human development index in accordance with the UN Project methodology, were included in the list of leading countries in terms of the intensity of expenditures on technological innovation and / or the total level of innovative activity of organizations in 2017 (Fig. 2-4). The lack of data on the innovative development of individual countries in the figure is due solely to their absence in national statistical observation systems.

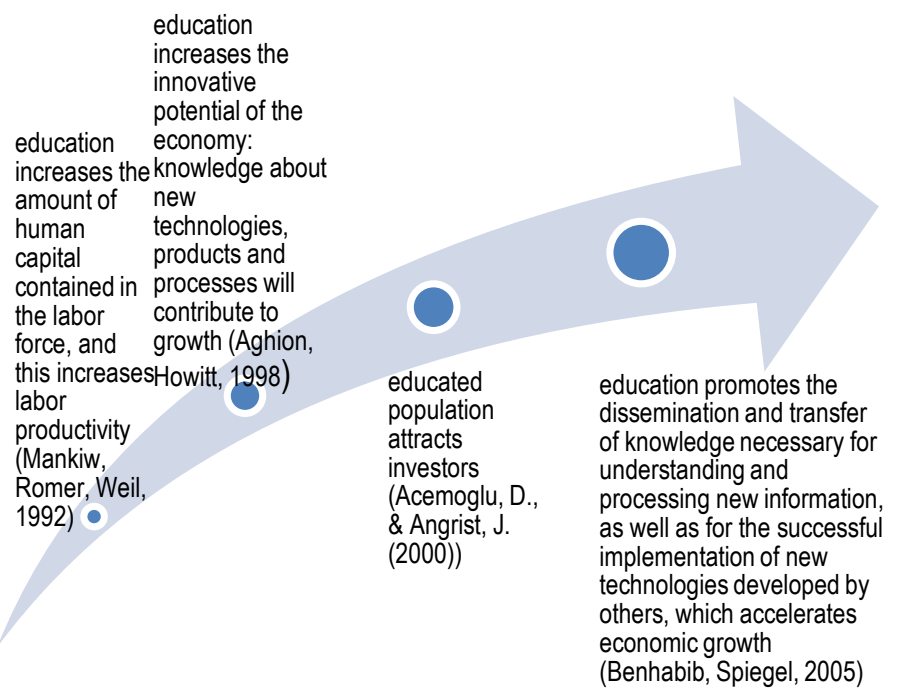

Fig. 1. Genesis of classical concept of human capital

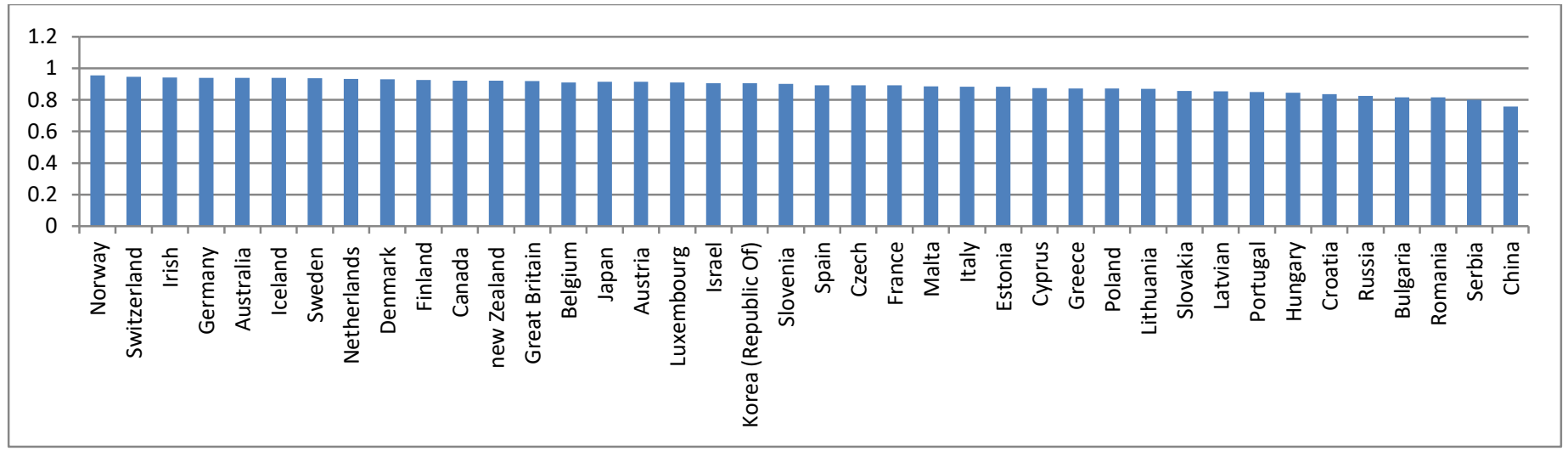

Fig. 2. Human Development Index [8]

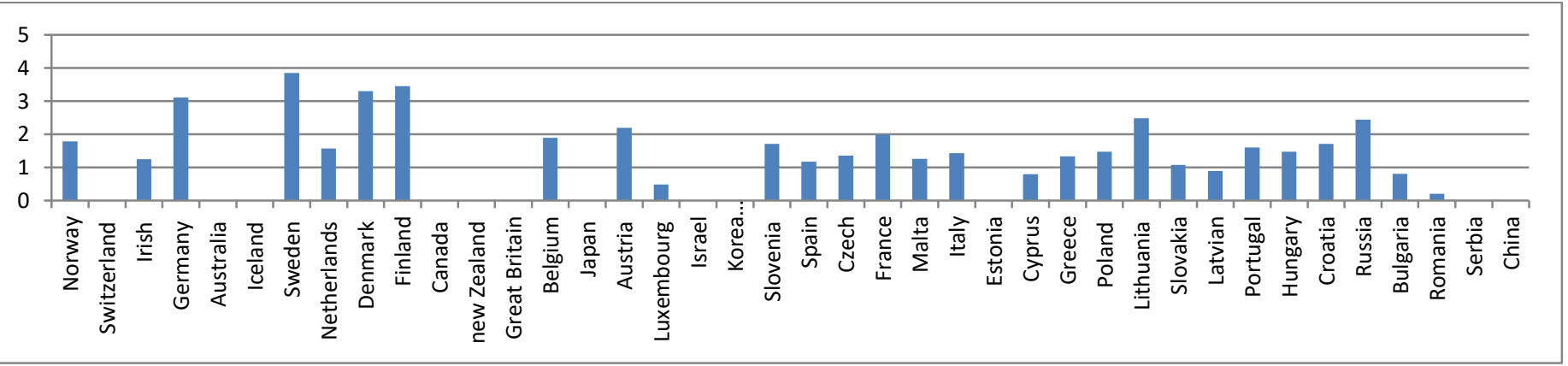

Fig. 3. Expenditure intensity of technological innovation [9] 


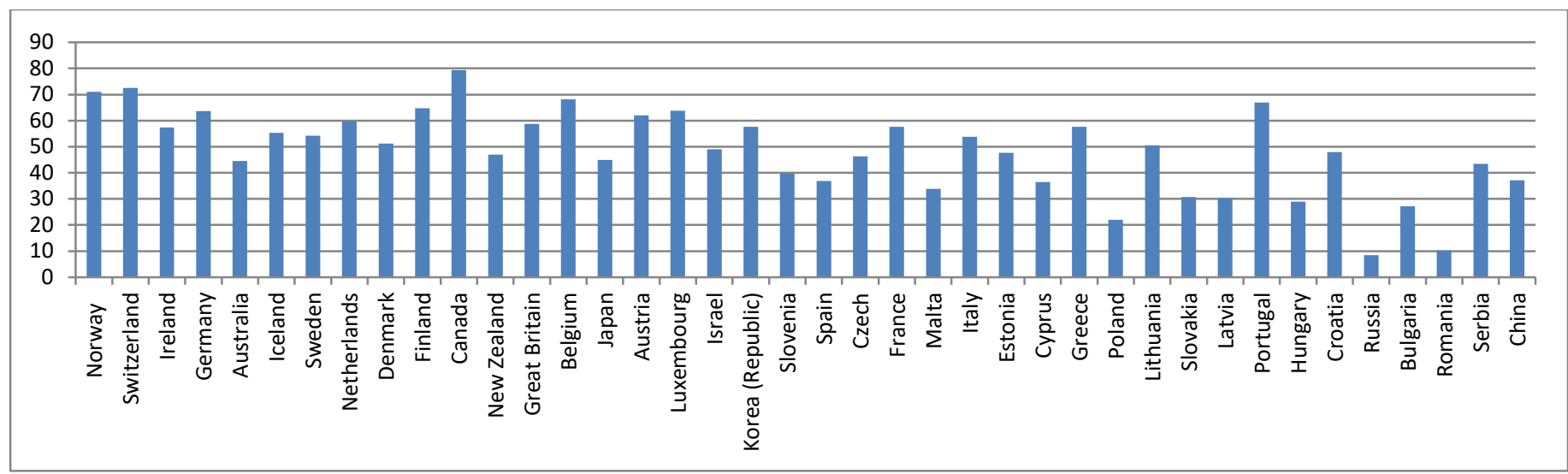

Fig. 4. Total level of innovative activity of organizations [9]

Thus, the concept of human capital is being transformed in terms of its relationship with economic growth and understanding of the role of economic growth as the main engine for education development. Improving the effectiveness of investment in education in the framework of human capital management for innovative development is possible only in the context of the integration of science, education and business in training in the context of new paradigm of the relationship between human capital and economic growth in an innovative economy, where investment in innovation and technology is considered as the main engine of education development (Figure 5).

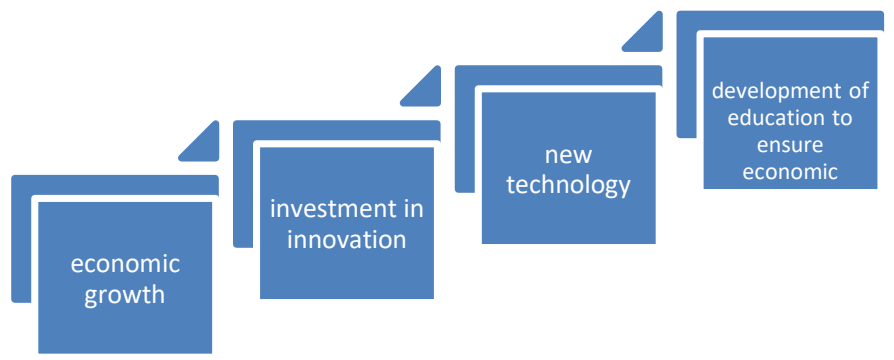

Fig. 5. Diagram of a new concept of human capital

So at the beginning of the XIX century in England $90 \%$ of the population was illiterate, and already at the end of the XIX century - only $3 \%$. Economic growth, investment in technology and fixed assets required the development of education. Today the rapid mass introduction of digital technologies entails the need to change professions in terms of the set of competencies (digital competencies), and, consequently, the vocational training system [10].

The appropriate index is used to characterize human potential. Its dynamics for Russia is influenced by factors of a decrease in the number and deprivation of the working-age population (Table I).

According to the data from the World Bank, presented in the report "The Changing Wealth of Nations 2018: Building a Sustainable Future", $64 \%$ of the world's capital is human capital in the structure of the wealth of countries on average, this share is $70 \%$ in high-income countries and $41 \%$ - in countries with low income. Capitalized human potential occupies $48 \%$ in the structure of Russia's wealth. Moreover, up to $50 \%$ of differences between countries' incomes are determined by the level of human capital. In this World Bank report, Russia's total wealth is estimated at $\$ 188,700$ per capita. Most of welfare gain in Russia has been achieved due to the gross rate of productivity. The high and growing level of human capital in Russia will give the country a chance to cope with new challenges.

TABLE I. DYNAMICS OF HUMAN POTENTIAL CHARACTERISTICS IN RUSSIA

\begin{tabular}{|l|l|l|l|l|l|l|}
\hline & $\mathbf{2 0 0 1}$ & $\mathbf{2 0 0 5}$ & $\mathbf{2 0 1 0}$ & $\mathbf{2 0 1 6}$ & $\begin{array}{c}\mathbf{2 0 2 0} \\
\text { (predictive } \\
\text { information) }\end{array}$ & $\begin{array}{c}\mathbf{2 0 3 0} \\
\text { (predictive } \\
\text { information) }\end{array}$ \\
\hline $\begin{array}{l}\text { Life Expectancy } \\
\text { Index }\end{array}$ & 0.672 & 0.683 & 0.710 & 0.738 & 0.762 & 0.783 \\
\hline Education Index & 0.848 & 0.791 & 0.794 & 0.816 & 0.862 & 0.882 \\
\hline $\begin{array}{l}\text { GDP Index per } \\
\text { capita }\end{array}$ & 0.729 & 0,739 & 0.768 & 0.854 & 0.899 & 0.944 \\
\hline $\begin{array}{l}\text { Human } \\
\text { Development } \\
\text { Index }\end{array}$ & 0.723 & 0.741 & 0.766 & 0.816 & 0.827 & 0.858 \\
\hline
\end{tabular}

Over the past 2 decades in Russia, a country with a traditionally high level of human development, the continuous growth of human development index (according to UNDP methodology) has been accompanied by a decrease in economic growth rates, estimated through the volume of real gross domestic product (according to the IMF), shown in Figure 6.

The presented ratio can be explained by the insufficient growth rate of the human development index (for the period from 1990 to 2017, the human development index of Russia grew by $11 \%$, while Russia fell by the value of this indicator from 31 to 50 places in the world) and the faster growth of human capital in other countries amid international integration and economic globalization. A similar situation is recorded in the USA and Japan. Norway, Germany, Poland, China, and others have significantly strengthened their positions in the international field of human capital formation over the 20 -year period under study. 


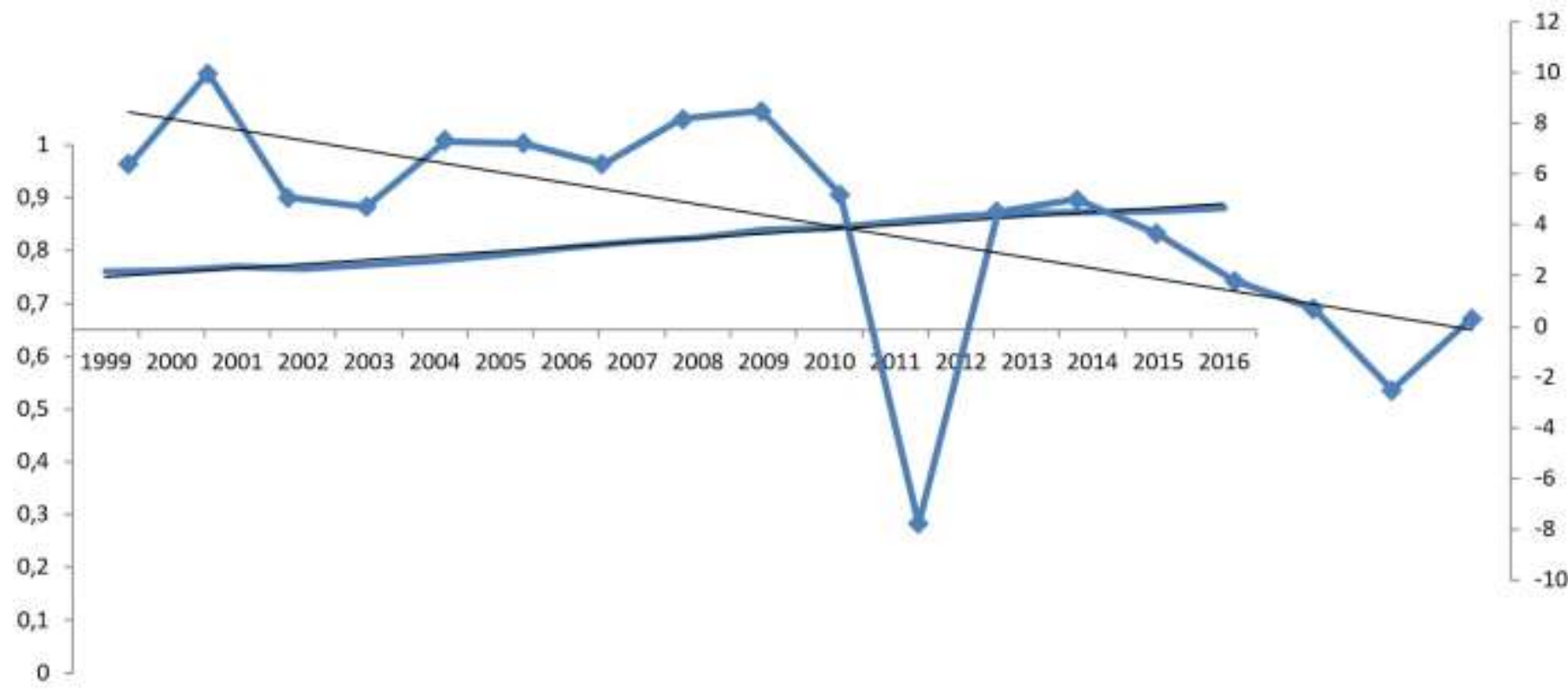

Fig. 6. Human Development Index in Russia: left scale, data series without markers [12 -17]; Russia's economic growth rates, \%: right scale, data series with markers [18]

At the same time the human development index advance is accompanied by an increase in the quality of education in Russia. According to the international study of educational achievements of PISA students, from 2000 to 2015, the level of reading, mathematics and science literacy has steadily increased in Russia. At the same time Russia took the 34th place in the world in the international ranking of the effectiveness of national education systems in 2016, and the leader of the national education system - Lomonosov Moscow State University was ranked 90th in 2018 [19]. In the global ranking of digital competitiveness in 2018, Russia ranks 40th in the world, losing 10 positions to China.

Thus, in international practice the Russian economy is distinguished by a unique combination of a high level of human capital development with low rates of economic and innovative development. One of the world's strongest national education systems forms the unclaimed human potential and leads to the burning of acquired competencies. Within the country, there is a significant regional differentiation in terms of educational potential, innovative development, and the human development index, as noted by researchers earlier.

At present, in Russia there is a low susceptibility of enterprise employees to innovations and an insufficiently high level of innovative development of socio-economic systems, manifested both in the insufficiency of the formed innovative potential and in the low activity of its use [20]. In Russia the policy pursued by the government in the field of development and financing of innovations did not lead to the expected level of innovative development of the economy [21]. Investments even in high-tech industries do not give the desired result, which makes it difficult to achieve the goals of establishing an innovatively oriented digital economy and ensuring its global competitiveness. Over a period of 2 decades, the number of personnel engaged in research and development has been steadily declining in Russia (Table II).

TABLE II. DYNAMICS OF NUMBER OF EMPLOYEES ENGAGED IN RESEARCH AND DEVELOPMENT BY CATEGORY (PERSON)

\begin{tabular}{|c|c|c|c|c|c|c|c|}
\hline & 2000 & 2005 & 2010 & 2013 & 2014 & 2015 & 2016 \\
\hline Number of employees-total & 887729 & 813207 & 736540 & 727029 & 732274 & 738857 & 722291 \\
\hline \multicolumn{8}{|l|}{ including: } \\
\hline researchers & 425954 & 391121 & 368915 & 369015 & 373905 & 379411 & 370379 \\
\hline technicians & 75184 & 65982 & 59276 & 61401 & 63168 & 62805 & 60441 \\
\hline support staff & 240506 & 215555 & 183713 & 175365 & 173554 & 174056 & 171915 \\
\hline other personnel & 146085 & 140549 & 124636 & 121248 & 121647 & 122585 & 119556 \\
\hline
\end{tabular}

${ }^{\text {b. }}$ Compiled by the author based on [11]

Innovative activity and susceptibility of population to innovation can be achieved using human capital management tools in the interests of innovative development. Some companies have already established good practices that contribute to the realization of company's hidden capabilities through the conscious initiative of employees. There are some of them, which are a reaction to prevailing global trends and challenges of labor market in the context of digitalization of the economy.

Reverse mentoring is a technology that allows you to reduce the gap between generations, based on the idea of cooperation between young workers and the older generation 
to help older colleagues in issues such as new and digital technologies, modern culture. The technology is particularly relevant in the face of rapid changes and the flow of digital innovations.

The development of digital tools in the direction of use digital technology allows you to create platforms that integrate all the activities of labor entities within the company. Based on the goals of campaign, digital-expertise (for example, through cross-collaboration with Google) makes it possible to select the appropriate personal tools for managing employee experience, evaluate the conversion of candidates and adjust the activity of platform users.

Augmented workforce arises as a result of the introduction of cognitive technologies and an open talent economy, as a result of which modern companies are forced not only to change the design and organization of work processes, but also to manage a workforce consisting of people, robots and artificial intelligence working side by side.

Artificial intelligence in working with candidates and employees is the basis for customizing human resources management tools by designing them with the participation of the employee as an internal client. Such tools allow HR specialists to find candidates more accurately and efficiently, as well as to model and implement their development within the company.

Talent swaps in connection with the change in the general organizational paradigm and the transition of companies around the world from a rigid hierarchical model to flexible team networks implies succession planning and involves organizing a process related to the development of such qualities and skills as collaboration and coaching.

\section{CONCLUSION}

Along with the need to use new technologies and innovative tools for managing human capital for the development of digital economy, the core of national human capital remains the well-being of population, which is maintained and enhanced through a social protection system. Among other types of economic growth resources, knowledge has taken a stable leading position. Systemic paradigm of human capital of an innovative economy is formed as a research concept that implements and concretizes a holistic approach to identifying patterns and cause-effect relationships within the human capital system of innovative development, based on innovation and use of knowledge and takes into account the paradigm of the status of managerial science.

\section{References}

[1] N.G. Mankiw, D. Romer, D. Weil, "A contribution to the empirics of economic growth", Quarterly J. of Econ., vol. 107, no. 2, pp. 407-437, May 1992.

[2] P. Aghion, P. Howitt, Endogenous Growth Theory, Cambridge, MA: MIT Press, 1998.
[3] D. Acemoglu, J.D. Angrist, "How large are the social returns to education? Evidence from compulsory schooling laws", In NBER Macroeconomics Annual 2000. Cambridge, MA: MIT Press, 2000, pp. 90-59.

[4] J. Benhabib, M.M. Spiegel, "Human capital and technology diffusion", In Handbook of Economic Growth. Amsterdam: North Holland, 2005, pp. 935-966.

[5] Deloitte Global Human Capital Trends, 2017, p. 4, Retrieved from: https://www2.deloitte.com/insights/us/en/focus/human-capitaltrends/2017/introduction.html

[6] E. Lyapuntsova, Y. Belozerova, I. Drozdova, G. Afanasev, E. Okunkova, "Entrepreneurial Risks in the Realities of the Digital Economy" [MATEC Web of Conferences, vol. 251, no. 06032, 2018], DOI: 10.1051 / matecconf / 201825106032.

[7] E. Hanushek, L. Woismann, "The Role of Education Quality in Economic Growth", World Bank Policy Res., WP, no. 4122, 2007.

[8] Inequalities in human development in the 21st century, Beyond income, beyond averages, beyond today, Human Development Report 2019. Retrieved from: http://report.hdr.undp.org

[9] L. Gokhberg, K. Ditkovskiy, I. Kuznetsova et al., Indicators of Innovation in the Russian Federation: 2019, Data Book. Moscow: HSE, 2019

[10] O.V. Ovchinkin, A.I. Pykhtin, E.A. Bessonova, E.V. Kharchenko, N.B Chernykh, "System of internal monitoring of performance of indicators of efficiency of the university", Int. J. of Advan. Trends in Computer Sci. and Engineer., vol. 8, no. 6, pp. 3312-3317, 2019.

[11] L. Gokhberg, K. Ditkovskiy, E. Diachenko et al., Science and Technology Indicators in the Russian Federation: 2019, Data Book. Moscow: HSE, 2019.

[12] Doklad o chelovecheskom razvitii v Rossiyskoy Federatsii za 2018 god, pod red. S.N. Bobyleva i L.M. Grigor'yeva. Moscow: Analiticheskiy tsentr pri Pravitel'stve Rossiyskoy Federatsii, 2018, 172 p.

[13] Doklad o chelovecheskom razvitii v Rossiyskoy Federatsii za 2017 god, pod red. S.N. Bobyleva i L.M. Grigor'yeva. Moscow: Analiticheskiy tsentr pri Pravitel'stve Rossiyskoy Federatsii, 2017, 292 p.

[14] Doklad o chelovecheskom razvitii v Rossiyskoy Federatsii za 2016 god, pod red. S.N. Bobyleva i L.M. Grigor'yeva. Moscow: Analiticheskiy tsentr pri Pravitel'stve Rossiyskoy Federatsii, 2016, 298 p.

[15] Doklad o chelovecheskom razvitii v Rossiyskoy Federatsii za 2015 god, pod red. L.M. Grigor'yeva i S.N. Bobyleva. Moscow: Analiticheskiy tsentr pri Pravitel'stve Rossiyskoy Federatsii, 2015, 260 p.

[16] Doklad o chelovecheskom razvitii v Rossiyskoy Federatsii za 2014 god, pod red. L.M. Grigor'yeva i S.N. Bobyleva. Moscow: Analiticheskiy tsentr pri Pravitel'stve Rossiyskoy Federatsii, 2014, 204 p.

[17] Doklad o chelovecheskom razvitii v Rossiyskoy Federatsii za 2013 g., Pod obshchey redaktsiyey S.N. Bobyleva. Moscow: OOO «RA IL'F», 2013, 202 p.

[18] National Human Development, Report 2011 for the Russian Federation, ed. by A. Auzan and S. Bobylev. Moscow, 2011, 142 p.

[19] Report for Selected Countries and Subjects, Retrieved from: https://www.imf.org/external/pubs/ft/weo/2018/01/weodata/weorept.asp $\mathrm{x}$ ? $\mathrm{sy}=1992 \& \mathrm{ey}=2023 \& \mathrm{scsm}=1 \& \mathrm{ssd}=1 \&$ sort $=$ country $\& \mathrm{ds}=. \& \mathrm{br}=1 \& \mathrm{c}=9$ 22\&s=NGDP_RPCH,PPPGDP,PPPPC,PCPIPCH,LUR,GGXWDG_NG $D P \& g r p=0 \& a=\& p r . x=36 \& p r . y=5$.

[20] N.A. Serebryakova, I.V. Avdeev, "The content of structural transformations of the region's economy, adequate to the requirements of digitalization", Proc. of Voronezh State Univer. of Engineer. Technol., vol. 80, no. 4, pp. 408-412, 2018, Retrieved from: https://doi.org/10.20914/2310-1202-2018-4-408-412.

[21] N.A. Serebryakova, A.V. Petrikov, "The principles of design and the organization of functioning of innovative infrastructures in the conditions of the Industry 4.0.”, Proc. of Voronezh State Univer. of Engineer. Technol., vol. 80, no. 4, pp. 384-387, 2018. Retrieved from: https://doi.org/10.20914/2310-1202-2018-4-384-387. 